\title{
Violações a Direitos Humanos por Empresas Transnacionais na América Latina Perspectivas de Responsabilização
}

\begin{abstract}
Ana Carolina Lopes Olsen
Doutoranda em Direito pela Pontifícia Universidade Católica do Paraná, na linha de pesquisa Justiça, Direitos Humanos e Democracia. Graduação em Direito (2000) e Mestrado em Direito (2006) pela Universidade Federal do Paraná. Visiting Researcher no Instituto Max Planck para Direito Público Comparado e Direito Internacional, Heidelberg, 2019. Professora do curso de Direito do Centro Universitário Católico SC, Unidade de Joinville. anac.olsen@gmail.com
\end{abstract}

\section{Danielle Anne Pamplona}

Professora titular da Pós-Graduação e da Graduação da Pontifícia Universidade Católica do Paraná. International Visiting Scholar na Washington College of Law na American University em Washington, DC (2015-2016). Doutorado em Direito pela Universidade Federal de Santa Catarina (2006). Mestrado em Direito pela Pontifícia Universidade Católica de São Paulo (2000) e Graduação em Direito pela Universidade Federal do Paraná (1995).dapamplona@pamplonaebraz.com.br

Em virtude da constatação das graves violações de direitos humanos perpetradas por empresas transnacionais, e sua baixa responsividade, o presente estudo buscou identificar e discutir quais os fundamentos e mecanismos que o Direito Internacional dos direitos humanos oferece para promover a responsabilização civil desses atores privados, com foco na realidade latino-americana. A América Latina tem sido palco da atuação irresponsável de transnacionais em virtude de seu quadro social deficitário e da baixa institucionalidade na proteção dos direitos humanos. Pelo método hipotético-dedutivo, e mediante pesquisa bibliográfica, verificou-se fundamentos para deduzir a vinculação de empresas transnacionais a instrumentos internacionais de proteção aos direitos humanos, o que pode autorizar sua responsabilização perante os Estados em que praticam a violação, ou perante os Estados em que mantêm o controle de sua atividade econômica e cadeia produtiva. Uma terceira hipótese, mais controversa, é a aplicação da jurisdição universal, cujo delineamento ainda carece de adesão dos Estados, mas já dá sinais de viabilidade, na medida em que se associa a responsabilidade civil à penal internacional.

Palavras-chave: Empresas transnacionais. Direitos humanos. Responsabilidade civil. Estado. Violação.

\section{HUMAN RIGHTS VIOLATIONS BY TRANSNATIONAL CORPORATIONS IN LATIN AMERICA: LIABILITY PERSPECTIVES}

\section{ABSTRACT}

In view of the serious violations of human rights perpetrated by transnational corporations and their low responsiveness, the present study sought to identify and analyze the foundations and mechanisms that international human rights law offers to promote the accountability of these private actors, focused on the Latin American reality. Latin America has been the scene of the irresponsible performance of transnational corporations because of its deficit and weak institutional framework for the protection of human rights. Through the hipothetical-deductive method, and by bibliographical research, it has been found that transnational corporations are bound by international legal obligation to respect human rights, and may be held liable for their acts both by states where they violate these rights, and by those in which they keep control of their economic activity and chain of production. A third and more controversial possibility is the civil liability through universal jurisdiction, which becomes viable if criminal and civil responsibility are associated.

Keywords: Transnational corporations. Human rights. Liability. State. Violation.

\section{SUMÁRIO}

1 Introdução. 2 Violações de direitos humanos por empresas transnacionais na América Latina. 3 Vinculação das empresas transnacionais às normas de direitos humanos. 3.1 Vinculação indireta a tratados de direitos humanos. 3.2 Mecanismos de soft law. 4 Responsabilização das empresas por violações de direitos humanos perante os Estados. 4.1 Responsabilização perante Estados de acolhimento ("Host States"). 4.2 Responsabilização perante Estados de origem ("Home States"). 4.3 A proposta da jurisdição universal. 5 Conclusão. 6 Referências. 


\section{INTRODUÇÃO}

A preocupação com a proteção e o respeito aos direitos humanos não mais se restringe à atuação estatal. Graves violações de direitos humanos são identificadas todos os dias a partir da atuação de empresas privadas que exploram populações com pouca proteção jurídica. Estas empresas atuam em diversos Estados do globo, comumente procurando deslocar as atividades mais perigosas ou danosas aos direitos humanos para aqueles países cujo sistema jurídico mantém lacunas que permitem que sua atuação - mesmo contrária a regras às quais deva se submeter a matriz - viole direitos humanos.

Essa realidade tem tocado de perto Estados da América Latina, evidenciando violações de direitos humanos desencadeadas por empresas transnacionais que se instalam com promessas de empregos e investimento econômico, mas deixam atrás de si deslocamentos forçados, violação de direitos de comunidades indígenas e tradicionais, contaminação de rios e solos, trabalho escravo. Situações como essas não podem ficar à margem da responsabilidade jurídica.

Diante desse quadro, a pesquisa buscou propor fundamentos e mecanismos a partir do direito internacional dos direitos humanos para promover a responsabilidade civil desses atores privados, com foco voltado para a realidade latino-americana.

Ressalta-se que o foco adotado foi de responsabilização civil, mais promissor que o penal, por uma série de fatores: (i) afasta dificuldade inerente ao reconhecimento da responsabilidade penal de pessoas jurídicas; (ii) desestimula violações em razão de condenações vultosas, bem como alerta os acionistas desejosos de proteção do seu capital; (iii) pode ser desencadeada diretamente pelas vítimas ou seus representantes; (iv) exige apenas provas que indiquem a preponderância da evidência (MONGELARD, 2006, p. 666-667).

Procurou-se inicialmente apresentar as formas como empresas transnacionais têm atuado na América Latina, as espécies de violações de direitos humanos e como os Estados e o sistema regional têm lidado com essa realidade.

Num segundo momento procurou-se demonstrar a possibilidade de se extrair diretamente do sistema jurídico internacional de proteção dos direitos humanos uma obrigação geral de respeito por parte desses atores privados, seja mediante uma vinculação indireta a tratados internacionais já existentes, seja por meio do fortalecimento da concepção de soft law, que corresponde à maior parte dos documentos jurídicos internacionais que tratam de empresas e direitos humanos. Importante esclarecer, contudo, que na ausência de um tratado internacional que vincule diretamente as empresas transnacionais, as possibilidades de responsabilização passam, necessariamente, pela atuação dos Estados.

Nesse sentido, na terceira parte o estudo focou em três possibilidades de responsabilização das empresas transnacionais: (i) perante os Estados em que elas mantêm suas atividades, e que representam o palco das violações; (ii) perante os Estados de origem das empresas, mediante a perspectiva da jurisdição extraterritorial e (iii) mediante atuação da jurisdição universal, voltada para o combate a graves violações de direitos humanos, como crimes contra a humanidade. 


\section{Democracia}

A metodologia empregada foi a pesquisa exploratória em doutrina e jurisprudência, utilizando-se ora o método dedutivo, para, partindo das premissas do direito internacional dos direitos humanos, extrair a responsabilidade das empresas transnacionais; ora o método indutivo, em que o estudo de casos julgados por Cortes e sistemas jurídicos diversos contribuiu para refletir sobre as formas de responsabilização dessas empresas.

\section{VIOLAÇÕES DE DIREITOS HUMANOS POR EMPRESAS TRANSNACIONAIS NA AMÉRICA LATINA}

Em tempos de intensa e deflagrada globalização econômica, os processos de coleta de matérias-primas, produção, distribuição e comercialização de produtos está longe de se concentrar exclusivamente em um só país. Diversas corporações ao redor do globo expandiram suas linhas de produção, enfraquecendo a soberania estatal na medida em que se verifica uma intensa circulação de bens e mercadorias, influenciando os processos de decisão política (LIMA, 2002, p. 146 et seq.). Empresas transnacionais - aqui entendidas como um organismo não centralizado, estruturado em uma rede produtiva instalada em múltiplos Estados com ações interdependentes a partir de uma racionalidade econômica (RAMONET apud LIMA, 2002, p. 148-149) - tornam-se importantes atores da conjuntura (e muitas vezes da estrutura) mundial.

Essa pulverização internacional das cadeias econômicas traz profundas influências jurídicas, políticas, econômicas, sociais e culturais, de modo que os Estados perdem o protagonismo na condução de todos os assuntos que tocam mais de perto a sociedade (CARDIA; GIANNATTASIO, 2016, p. 132-133). Nesse espectro, a falta de centros regulatórios capazes de controlar a racionalidade do lucro tem gerado efeitos nefastos para os direitos humanos. Diversas corporações sediadas na Europa e na América do Norte deslocam sua produção mais agressiva em termos socioambientais para Estados do Hemisfério Sul em busca de vantagens decorrentes da vulnerabilidade econômica e fiscalização mais frouxas em caso de potencial violação aos direitos humanos.

Nesse sentido, a América Latina é especialmente vulnerável (por razões econômicas, políticas, judiciais e sociais) à atuação desses grandes grupos econômicos, cujas receitas muitas vezes superam o PIB de Estados inteiros. ${ }^{1}$ Como bem salientou Piovesan (2015, p. 66), multinacionais são "as grandes beneficiárias do processo de globalização, bastando citar que, das cem maiores economias mundiais, 51 são empresas multinacionais e 49 são Estados nacionais".

Se, de um lado, as empresas transnacionais instalam-se propagandeando geração de empregos, desenvolvimento econômico e ampliação das opções para o mercado de consumo, sua atuação também implica em outro, bem menos atraente, com alterações profundas nas estruturas sociais, incremento das desigualdades e degradação ambiental. As populações locais acabam por não perceber os benefícios, mas sentem diretamente os prejuízos (KALECK; SAAGE-MAAß, 2008, p. 9; OKIMURA, 2012, p. 316-317).

General Motors e Wal-Mart auferem receita maior que o PIB de toda a África Subsaariana (OKIMURA, 2012, p. 316). 
Em virtude de limites pouco definidos ou definíveis do que é legal ou ilegal nesses países, severas violações de direitos humanos permanecem impunes (BÖHM, 2012, p. 11). Além disso, importa observar que no final do século 20, diversos países da América Latina empreenderam reformas neoliberais em seus sistemas jurídicos, tornando-se mercados atraentes para as corporações transnacionais (ZUBIZARRETA, 2009, p. 308).

A ThyssenKrupp Companhia Siderúrgica do Atlântico, por exemplo, construiu na Baía de Sepetiba (Rio de Janeiro, Brasil), a maior central siderúrgica da América do Sul, sem as devidas licenças, poluindo as águas com arsênico e chumbo em prejuízo do emprego e da saúde de pescadores artesanais e suas famílias. Muitos que resistiram foram ameaçados e reprimidos, inclusive com mortes ainda não esclarecidas (BÖHM, 2012, p. 13).

Na Colômbia, a empresa norte-americana Chiquita Brands financiou as milícias colombianas, entre 1997 e 2004, possibilitando que deslocassem forçadamente as populações que viviam do plantio da banana. Essas vítimas jamais foram indenizadas pela empresa, uma vez que a investigação penal conduzida pelas instituições colombianas a respeito dos pagamentos concluiu pela preclusão do caso e pela ausência de provas de que o dinheiro fornecido teria sido utilizado para a perpetração de massacres (BÖHM, 2012, p. 14).

Outros exemplos importantes foram analisados por Kaleck e Saagen-Maaß (2008, p. 10): casos envolvendo uma fábrica de celulose montada pela transnacional Finnish em Botnia, no Uruguai; as disputas jurídicas entre Brasil e União Europeia na OMC em razão da vedação legal brasileira à importação de pneus usados; os graves conflitos havidos entre o Movimento Sem Terra, no Brasil, e milícias privadas contratadas pela Corporação Suíça Syngenta, a fim de garantir o plantio de sementes geneticamente modificadas que não poderiam ser replantadas; e ainda as péssimas condições de trabalho dos "sweatshops" na Grande Buenos Aires, decorrentes de contratações ilegais de mão de obra de migrantes bolivianos em favor das marcas Puma, Adidas e Le Coq Sportif. Esse último caso evidencia a própria lógica muitas vezes empreendida por transnacionais: maior será seu lucro se menor for sua responsabilidade pelos direitos das pessoas envolvidas no processo de produção (RAMONET apud LIMA, 2002, p. 149).

Como ilustra o caso argentino, em grande parte das vezes os direitos humanos são violados diretamente por pequenos empreendimentos que integram a cadeia de produção das empresas transnacionais, as quais têm uma participação indireta nas violações. Essas pequenas empresas dificilmente são submetidas à pressão pública, e passam ao largo do controle dos "shareholders", o que dificulta ainda mais a configuração de eventual responsabilidade das transnacionais pelas violações (KALECK; SAAGEN-MAAß, 2008, p. 11).

Mesmo nos casos em que mecanismos administrativos e judiciais tenham sido desencadeados para reparar as violações aos direitos humanos, nenhum deles se mostrou eficaz (BÖHM, 2012, p. 15). Na medida em que os sistemas judiciais domésticos não logram satisfazer as pretensões de reparação das vítimas, seja pela morosidade imposta aos litigantes, que prejudica demandantes desempregados, por exemplo, seja pela diversidade de decisões, que estimula a interposição de recursos, eles acabam por incentivar violações por empresas transnacionais. "Os custos impostos pelo sistema judiciário são mais vantajosos do que a mudança no comportamento perante consumidores e seus empregados" (OKIMURA, 2012, p. 321). 


\section{Humanos e \\ Democracia}

A globalização, portanto, gera um quadro de facilitação da exploração econômica de populações em Estados com estrutura jurídica, social e política deficitária por empresas transnacionais. A pulverização das cadeias produtivas torna difícil a responsabilização das empresas diretamente beneficiadas, as quais lucram com violações de direitos humanos não devidamente reprimidas.

Não obstante, empresas transnacionais por vezes cooperam com violações de direitos humanos sem proveito econômico imediatamente aferível. Para além de situações em que (a) lucram com a violência praticada pelo Estado e (b) fornecem meios para colaborar com o regime de violação de direitos humanos, há (c) casos em que corporações diretamente apoiam a repressão sem nenhum benefício econômico direto. Exemplo desse último fato foi o apoio livremente dispensado pela Mercedes Benz à ditadura militar argentina, em que os dirigentes da empresa forneceram ao governo informações sobre o paradeiro e facilitaram a prisão, tortura e desaparecimento de seus empregados envolvidos em atividades consideradas subversivas. A Ford, por sua vez, permitiu que membros sindicais fossem presos e torturados em suas próprias instalações (KALECK; SAAGEN-MAAß, 2010, p. 703-707).

Apesar da superação de regimes ditatoriais latino-americanos, contudo, essas empresas não foram perseguidas. Essa falha na accountability deve-se em grande medida à continuidade das elites econômicas no poder, uma vez que são vistas como "atores-chave" no processo de reconstrução social, permanecendo impunes ainda que tenham contribuído para a injustiça do sistema (KALECK; SAAGEN-MAAß, 2010, p. 718).

Diante da inefetividade dos meios domésticos de proteção aos direitos humanos, torna-se necessário buscar alternativas que possibilitem responsabilizar empresas transnacionais (KALECK; SAAGEN-MAA $\beta, 2008$, p. 11). A reversão dessa realidade passa por duas questões centrais: se empresas transnacionais podem ser juridicamente responsabilizadas por violações de direitos humanos, e, sendo afirmativa essa resposta, perante qual jurisdição se poderia aplicar essa responsabilização.

\section{VINCULAÇÃO DAS EMPRESAS TRANSNACIONAIS ÀS NORMAS DE DIREITOS HUMANOS}

Ao se instalarem em um Estado, empresas transnacionais vinculam-se ao direito doméstico, devendo respeitar suas permissões e suas proibições. No sistema interamericano de direitos humanos, esta vinculação engloba tanto a legislação produzida por esse Estado (Constituição e demais leis) como também os tratados internacionais (inclusive de direitos humanos) de que esse Estado seja parte ${ }^{2}$ (CERQUEIRA, 2015, p. 20). Tomando o Brasil por referência, a empresa transnacional aqui instalada deve respeitar os direitos fundamentais previstos na Constituição, bem como os direitos humanos reconhecidos em tratados internacionais dos quais o Brasil seja parte. Em caso de violação, qualquer das vítimas poderia acioná-la perante

\footnotetext{
É o que se deprende do artigo 36 da Carta da Organização dos Estados Americanos: "Ias empresas transnacionales y la inversión privada extranjera están sometidas a la legislación y a la jurisdicción de los tribunales nacionales competentes de los países receptores y a los tratados y convenios internacionales en los cuales estos sean Parte y, además, deben ajustarse a la política de desarrollo de los países receptores" (CERQUEIRA, 2015, p. 20).
} 
o sistema jurídico nacional, a fim de que seja devidamente responsabilizada e arque com as consequências (reparação dos danos). Essa situação, contudo, suscita alguns questionamentos que merecem ser enfrentados.

Seria possível afirmar que as empresas transnacionais estariam vinculadas aos tratados internacionais de direitos humanos independentemente da postura adotada pelos Estados em que estabelecem suas atividades? A resposta implicaria a possibilidade de o ente jurídico privado estar obrigado a respeitar normas de direitos humanos mesmo que não haja esse comprometimento por parte do Estado. Nesse sentido, vale levar em consideração que os Estados Unidos e o Canadá não são signatários da Convenção Americana de Direitos Humanos, nem do Protocolo de San Salvador. Ainda, há que se avaliar que um Estado pode se retirar da OEA, como anunciou a Venezuela recentemente (MEZA, 2017). As empresas ali instaladas estariam, então, livres dos compromissos envolvendo direitos humanos estabelecidos nestes instrumentos internacionais? Se a resposta for negativa, é preciso justificá-la.

\subsection{Vinculação indireta a tratados de direitos humanos}

Reconhecer em empresas transnacionais destinatários diretos das obrigações decorrentes de normas internacionais de direitos humanos é matéria ainda sujeita à ampla discussão na doutrina. Essas corporações não estão vinculadas a nenhum tratado internacional de direitos humanos, apesar de inegavelmente exercerem imenso poder e influência nas condições econômicas, sociais e ecológicas pelo mundo (KALECK; SAAGE-MAA $\beta, 2008$, p. 12). Tal quadro representa uma grave assimetria, na medida em que a atuação das empresas transnacionais influencia a criação do Direito Internacional, mas elas não se submeteriam a ele.

Essa assimetria revela-se especialmente na evolução do Direito Comercial Internacional desacompanhada da vinculação aos Direitos Humanos Internacionais; isto é, as oportunidades técnicas que a globalização deu às empresas transnacionais e que possibilitaram a tutela de seus direitos comerciais "no aparecen acompañadas de una mínima evolución en la aplicación directa de las normas internacionales a las empresas transnacionales" (ZUBIZARRETA, 2009 , p. 671). Uma forma de corrigir essa assimetria pode estar precisamente no fortalecimento dos sistemas internacionais de direitos humanos, como contraponto necessário à lógica de persecução do lucro da atuação corporativa. O pleno respeito aos direitos da pessoa humana poderia representar um critério que eventualmente legitimasse suas atividades (ZUBIZARRETA, 2009, p. 293).

$\mathrm{Na}$ qualidade de pessoas jurídicas privadas, as corporações transnacionais não são tradicionalmente vistas como pessoas jurídicas de Direito Internacional. No máximo, seriam sujeitos desse Direito, a ser aplicado mediante a intervenção de um Estado (ZUBIZARRETA, 2009, p. 301). Quando esses Estados não conseguem impor adequadamente à atuação destas empresas limites no respeito aos direitos humanos - como frequentemente acontece na América Latina - as atividades econômicas transnacionais muitas vezes restam blindadas à luz do Direito Comercial Internacional (ZUBIZARRETA, 2009, p. 305).

Se de um lado, porém, é possível descrever teoricamente uma ordem mundial na qual os Estados progressivamente perdem poder na determinação das relações sociais, econômicas e políticas, também seria possível cogitar, em sentido prescritivo, de se defender que esse Estado de fato perca o poder para dar lugar a entidades não estatais, desde que elas se tor- 


\section{Humanos e}

Democracia

nem igualmente responsáveis perante a ordem internacional (BRABENDERE, 2009, p. 192). Como salienta Tomuschat (2014, p. 133), é preciso reconhecer nos direitos humanos uma premissa axiomática capaz de embasar os sistemas legais de todo o mundo (nacionais e internacionais), obrigando Estados, indivíduos e corporações. Essa pretensão, contudo, está longe de se tornar realidade. Daí a necessidade de se pensar alternativas.

Há quem defenda a responsabilização das empresas transnacionais no plano internacional, como se fossem autênticos sujeitos de Direito Internacional: em virtude de seu poderoso desempenho nas relações internacionais, deveriam também ter status de entidades legais internacionais a possibilitar a assunção de obrigações relativas a direitos humanos. Num sentido mais radical, Gunther Teubner propõe que o mundo se estruture a partir de uma ordem constitucional global, na qual todos sejam sujeitos de direitos e deveres, especialmente grandes corporações (em razão de sua influência na ordem mundial) (TEUBNER, 2003, apud KALECK; SAAGE-MAA $\beta, 2008$, p. 14-15).

Essa concepção, todavia, enfrenta muita resistência em razão de uma estrutura jurídica internacional ainda focada na capacidade jurídica dos Estados, bem como na ausência de diplomas normativos ou mecanismos processuais que comprometam diretamente empresas transnacionais (KALECK; SAAGE-MAA $\beta, 2010$, p. 719), além das dificuldades pragmáticas que a instituição de tal ideia implicaria, por exemplo, que Corte teria jurisdição sobre estas então novas personalidades de Direito Internacional ou que tipo de sanções poderiam ser eficazmente aplicadas.

Diante disso, Peters (2012, p. 244) defende que se incorpore no plano internacional a doutrina do efeito horizontal dos direitos fundamentais, própria do Direito Constitucional (third-party effect). Corporações transnacionais deveriam respeitar integralmente o direito doméstico criado e aplicado por Estados-partes desses tratados, no sentido de incorporar e colocar em prática internamente as normas internacionais. Assim, empresas poderiam ser responsabilizadas, dentro desses Estados, se falhassem em cumprir com os standards definidos pelos tratados. Caso o Estado falhasse na criação e aplicação desse direito (segundo os padrões internacionais), e somente nessa hipótese, poderia ser desencadeado um dever intergovernamental residual capaz de responsabilizar as empresas (PETERS, 2012, p. 244-245). Essa perspectiva lança luz para obrigações em relação a direitos humanos independentes do direito interno dos Estados.

Assim, empresas poderiam responder por desrespeito a normas de direitos humanos independentemente do reconhecimento de personalidade jurídica internacional. Elas têm obrigações na medida em que essas forem aplicadas pelos Estados em que mantêm suas atividades, até porque é o Estado que permite a constituição dessas empresas, definindo como podem ou não atuar (SILVA; PAMPLONA, 2016, p. 160). Reconhecer essas obrigações não exige modificar a estrutura jurídico-normativa do direito internacional dos direitos humanos, mas promover uma reinterpretação que o torne mais aberto à participação de corporações transnacionais como destinatárias de obrigações (BRABENDERE, 2009, p. 195).

Nessa mesma linha se posicionam Kaleck e Saage-Maaß (2010, p. 720): estando consolidado que um indivíduo (ator não estatal) pode ser responsabilizado por crimes contra direitos humanos, segundo o Direito Penal Internacional [Estatuto de Roma], não seria razoável deixar de reconhecer que corporações também tenham obrigações na condição de pessoas jurídi- 
cas. Assim, uma vez reconhecido que a natureza subjetiva das corporações transnacionais, como atores não estatais, não poderia impedir o reconhecimento de sua vinculação aos direitos humanos, suas obrigações derivariam de uma reinterpretação das normas internacionais de direitos (BRABENDERE, 2009, p. 197-198).

No Direito Internacional humanitário, a obrigação de reparar o dano foi prevista no artigo 3o da IV Convenção de Haia, de 1907, aplicável aos Estados em razão da conduta de seus agentes (MONGELARD, 2006, p. 668). No julgamento do Tribunal Internacional Militar, em Nuremberg, esse foi um dos fundamentos determinantes da possibilidade de responsabilização de dirigentes de empresas privadas que se beneficiaram do regime nazista, ou até mais, contribuíram para sua plena eficácia (casos Farben e Krupp). Embora o julgamento tenha tido natureza penal, e dirigido às pessoas individuais dos dirigentes empresariais, os atos das empresas foram analisados de forma autônoma, podendo-se assim concluir que as empresas, como pessoas jurídicas privadas, agiram diretamente na violação de direitos humanos, e poderiam ser responsabilizadas - ainda que não necessariamente na esfera penal (BAARS, 2013, p. 173).

Da Declaração Universal dos Direitos Humanos também se infere que entidades privadas estariam comprometidas com o respeito aos direitos humanos, pois seu preâmbulo dirige-se a "todo indivíduo e todo órgão da sociedade". Na mesma linha, o Pacto Internacional de Direitos Civis e Políticos (PIDCP) e o Pacto Internacional de Direitos Econômicos, Sociais e Culturais referem-se à obrigação de todos os "grupos de pessoas" de se absterem de praticar atos que objetivem destruir os direitos e liberdades neles previstos. Ainda, o artigo 3ㅇ, comum às quatro Convenções de Genebra, aplica-se a todas as partes envolvidas em um conflito (estatais ou não) (MONGELARD, 2006, p. 669-670).

Na mesma linha, o Comitê de Direitos Humanos criado pelo PIDCP já se pronunciou a respeito da responsabilização dos Estados pela tortura praticada por pessoas privadas. Além disso, determinou que os Estados garantam os remédios eficazes para combater tais práticas, o que diretamente afirmaria o dever de os Estados perseguirem agentes privados que as praticassem ou para com elas contribuíssem (PAUST, 2002, p. 815).

No tocante ao sistema interamericano, também da Convenção Americana de Direitos Humanos, permite-se depreender a responsabilidade de particulares em relação aos direitos humanos, ao estabelecer que "todas as pessoas têm deveres para com a comunidade e a espécie humana". Seu artigo 29 também trata de "grupos de pessoas", sem se restringir a Estados (PAUST, 2002, p. 814-815). Além disso, a Corte já teve oportunidade de asseverar a vinculação de particulares aos direitos humanos quando da Opinião Consultiva 18/03 sobre La Condición Jurídica y los Derechos de los Migrantes Indocumentados, ao afirmar que o direito humano à igualdade e não discriminação corresponde a ius cogens com efeitos erga omnes, razão pela qual atingem particulares (CANÇADO TRINDADE, 2015, p. 429).

A proibição de discriminação integra diversas normas protetoras de direitos humanos geradoras de obrigações para a comunidade humana (incluindo empresas transnacionais), como a proibição de atos de agressão, genocídio, direitos básicos da pessoa humana, proibição de escravidão. A característica de ius cogens deriva da erosão do princípio da reciprocidade no Direito Internacional, e sua substituição por normas com caráter de ordem pública, 


\section{Humanos e}

Democracia

gerando obrigações erga omnes, o que Ihes atribui natureza objetiva capaz de atingir todos os destinatários das normas jurídicas, sejam eles órgãos do poder público, sejam particulares (CANÇADO TRINDADE, 2015, p. 430).

Precisamente afirmando essa dimensão cogente, a própria Convenção Americana dos Direitos Humanos, no artigo 1ำ, exige dos Estados a obrigação de garantir o pleno exercício dos direitos humanos. Com isso, deduz-se que no âmbito doméstico, tanto os órgãos estatais devem proteger direitos humanos, quanto os particulares devem respeitar - ou do contrário o Estado estaria obrigado a intervir para exigir esse respeito (CANÇADO TRINDADE, 2015, p. 431). Parece certo afirmar que indivíduos e empresas estão vinculados a esses tratados (AUTOR, 2016).

Assim, Cançado Trindade perfila-se ao lado de Paust (2002, p. 817), bem como de Mongelard (2006, p. 667) quando este conclui que "a ideia de que o direito internacional se aplica a atores não estatais, e, portanto, a empresas, e que elas têm obrigações e responsabilidades perante a lei, não implica nenhum problema conceitual".

\subsection{Mecanismos de soft law}

Para além dos tratados, existem previsões específicas de soft law que demandam que as empresas respeitem os direitos humanos reconhecidos em tratados. Em 2003, a Comissão de Direitos Humanos das Nações Unidas tentou aprovar as denominadas "Normas sobre Responsabilidades de Corporações Transnacionais e Outras Empresas a Respeito de Direitos Humanos", que estabelecia que as empresas deveriam compensar pessoas, entidades ou comunidades afetadas por atos em descumprimento das responsabilidades previstas no instrumento (MONGELARD, 2006, p. 671-672), todavia, por serem demasiadamente impositivas às corporações, foram rejeitadas.

Essas normas teriam vindo em resposta à proposta feita em 1999, pelo então Secretário-Geral da ONU, Kofi Annan, para vinculação das empresas transnacionais, chamada Pacto Global, a qual contou com o apoio da Câmara Internacional do Comércio - ICC. O programa estabelece dez princípios voltados a medidas anticorrupção, defesa do meio ambiente, respeito aos direitos humanos e à legislação trabalhista e se baseia na capacidade autorregulatória das empresas, cuja adesão se dá nas bases do voluntarismo (LOPES, 2014, p. 11). De fato, o número de empresas que aderiram ao Pacto Global foi significativo (cerca de 12 mil), porém seus princípios não especificaram punições para corporações que deixem de cumprir suas disposições, comprometendo sua efetividade (CARDIA; GIANNATTASIO, 2016, p. 133; SILVA; PAMPLONA, 2016, p. 152). Se o Pacto Global (2000) mostrou-se de baixa efetividade, as Normas sobre Responsabilidades de Corporações Transnacionais (2003), por sua vez, sequer foram aprovadas pela Assembleia Geral das Nações Unidas.

Como resposta, em 2005 John Ruggie, a pedido do Secretário-Geral das Nações Unidas, apresentou ao Conselho de Direitos Humanos da ONU os Princípios Orientadores da ONU sobre Empresas e Direitos Humanos: os então batizados "Princípios Ruggie" (Resolução A/ HRC/17/4). Referidos princípios estabeleceram os parâmetros "Proteger, Respeitar e Reparar" para o relacionamento entre Estados, empresas e direitos humanos: cabe aos Estados prote- 
ger os direitos humanos contra violações decorrentes de atos de terceiros; empresas têm a responsabilidade de respeitar os direitos humanos e as vítimas de violações devem ter facilitado o acesso às vias de reparação (SILVA; PAMPLONA, 2016, p. 153).

Embora ainda configurando soft law, referidos princípios impulsionaram a criação de um grupo de trabalho junto ao Conselho de Direitos Humanos para elaborar um tratado internacional capaz de vincular Estados e empresas aos direitos humanos (Resolução A/HRC/26/L.22/Rev.1). Enquanto referido tratado não é produzido, é dever dos Estados se vincularem aos Princípios Ruggie e estabelecerem domesticamente um Plano Nacional definindo parâmetros legais para a atuação de empresas em respeito aos direitos humanos (CARDIA; GIANNATTASIO, 2016, p. 134-135).

Nessa linha, os Princípios Ruggie, ainda que classificados como soft law, não podem ser desprezados, posto que, assim como todas as normas jurídicas, correspondem a um referencial normativo para a produção de outras normas jurídicas ou parâmetro para a adoção de condutas, sendo reconhecidos como referencial legítimo pelos seus destinatários. Progressivamente, essas normas influenciam práticas nacionais e internacionais, tornando-se parâmetros capazes de orientar ações de Estados e particulares (TOMUSCHAT, 2014, p. 46). Às normas jurídicas de soft law falta apenas a chamada garantia normativa, pois não estão acompanhadas de mecanismos jurídicos capazes de assegurar seu cumprimento.

Nem só de mecanismos de eficácia stricto sensu, todavia, sobrevivem as normas jurídicas. Elas são dotadas de institucionalidade quando se projetam em sua validade, de modo que arranjos institucionais podem determinar seu cumprimento. Na medida em que o Direito não se limita a restrições de comportamentos, mas tem também caráter institucional, será o grau de inventividade dos arranjos institucionais que poderá definir ou enriquecer a garantia normativa (CARDIA; GIANNATTASIO, 2016, p. 139).

Essa institucionalidade, contudo, não se estrutura em toda a América Latina. É preciso ressaltar que apenas a Colômbia ${ }^{3}$ e o Chile lançaram seus Planos de Ação em consonância com os Princípios Ruggie. O Brasil, até o momento, não aderiu a essa normativa. Nem sempre parece haver interesse na persecução de empresas violadoras de direitos humanos (BÖHM, 2012, p. 22). Depender dos Estados pode ser problemático.

\section{RESPONSABILIZAÇÃO DAS EMPRESAS POR VIOLAÇÕES DE DIREITOS HUMANOS PERANTE OS ESTADOS}

A responsabilização das empresas por violações a direitos humanos depende em grande parte da configuração do Direito doméstico, na medida em que incumbe aos Estados criar normas jurídicas que viabilizem investigações, processamento, julgamento e exigência de reparação (MONGELARD, 2006, p. 673).

\footnotetext{
3 Para o Plano de Ação Nacional colombiano, veja http://www.ohchr.org/Documents/Issues/Business/NationalPlans/PNA_ Colombia_9dic.pdf (Acesso em: 16 jul. 2017).
} 


\section{Humanos e}

Democracia

Como na América Latina muitos Estados partilham um contexto histórico de profunda desigualdade social, democracias ainda em processo de consolidação, déficit institucional de proteção de direitos humanos (PIOVESAN, 2015, p. 137), empresas transnacionais acabam por se beneficiar na tentativa de elisão da responsabilidade civil por violações a esses direitos.

Diante desse quadro, e considerando a importância que os Estados exercem no processo de responsabilização das empresas, três situações diferentes merecem ser analisadas: a que trata da relação entre as empresas e os Estados em que se instalam ("Host State"); a que trata da possibilidade de se acionar o Estado em que a corporação mantém a sua matriz ("Home State") e, finalmente, a proposta de responsabilização via jurisdição universal.

\subsection{Responsabilização perante Estados de acolhimento ("Host States")}

Pensar a jurisdição a ser provocada para responsabilizar empresas transnacionais não pode prescindir de uma análise preliminar sobre quais seriam as práticas que poderiam desencadear essa responsabilização.

A responsabilidade civil exige basicamente três elementos: violação ao direito (" $a$ wrong"), dano e a relação de causalidade entre esses dois (MONGELARD, 2006). Nessa perspectiva, a imputabilidade de uma violação a direitos humanos a corporações transnacionais surgirá quando ela age diretamente na produção do dano - como se verificou com os atos praticados por empresas na Alemanha nazista durante a Segunda Guerra Mundial. Empresas não alemãs se beneficiaram do uso do trabalho escravo, usurpação da propriedade de judeus, uso de trabalho de prisioneiros civis em condições subumanas. Esses atos, por si, representaram violações de direitos humanos, justificando a responsabilização dessas empresas (MONGELARD, 2006, p. 674-675).

Também os atos praticados por empregados da empresa, ou outras entidades a ela vinculadas (como terceirizadas) ensejam responsabilidade civil se violadores de direitos e ensejadores de dano (MONGELARD, 2006, p. 677). Esse tipo de responsabilização estará diretamente vinculado às modalidades de responsabilidade civil que o Direito nacional de cada Estado aplica, e no caso brasileiro deve ser verificada a presença dos seguintes requisitos: (i) o ato deve ser praticado por empregado da empresa ou pessoa física/jurídica a ela subordinada; (ii) o ato deve ser contrário à legislação que protege o direito humanos em tela e (iii) deve existir um dano imediatamente decorrente desse ato.

Finalmente, empresas podem ser responsabilizadas ainda que não ajam diretamente na produção do dano aos direitos humanos, mas sejam cúmplices daqueles que praticam a violação (especialmente os Estados, quando violam direitos para favorecer as atividades empresariais). Nesse caso, é fundamental que: (i) a violação tenha sido praticada por outra pessoa; (ii) a empresa tenha assistido a pessoa que praticou a violação (com recursos econômicos, facilitação de informações, entre outros); (iii) essa assistência tenha contado com o conhecimento e a intenção de ajudar na prática do crime (MONGELARD, 2006, p. 678).

Diante de práticas como essas, cabe aos Estados signatários da Convenção Americana de Direitos Humanos adotar medidas de responsabilização das empresas, a fim de se desincumbirem de sua obrigação de "proteger" e "garantir" direitos humanos, prevista no artigo 1 이 da Convenção. Esses Estados encontram-se vinculados a um lus Constitutionale Commune latino-americano, que se projeta a partir de um regime de cooperação entre Direito Público 
Interno e Internacional. O Direito Interno desses países, interconectado a partir de objetivos comuns - proteção dos direitos humanos, fortalecimento da democracia, redução das desigualdades sociais - teria a aptidão de responsabilizar com mais efetividade empresas transnacionais por suas violações (VON BOGDANDY, 2016, p. 12-13).

A responsabilidade dos Estados em relação a atos de particulares foi asseverada pela Corte Interamericana pela primeira vez quando do julgamento do caso Velasquez-Rodríguez vs. Honduras. A Corte condenou o Estado de Honduras pela falha na diligência em perseguir e punir particulares que promoveram o desaparecimento forçado da vítima (SANTOS, RIBEIRO, 2016, p. 387; CORTE..., 1988, parágrafo 172). Em outro caso, envolvendo o povo indígena Saramaka vs. Suriname, a Corte reconheceu que a legislação doméstica do Estado do Suriname era manifestamente insuficiente para garantir o direito de propriedade coletiva das terras do povo Saramaka, ao longo do Rio Suriname. Em razão disso, o Estado do Suriname concedeu a empresas os meios de exploração das terras indígenas para a construção de uma hidrelétrica, sem consultar o povo adequadamente; sem lhes garantir benefícios decorrentes dessa exploração capazes de compensar o uso de sua terra e sem exigir das empresas um estudo de impacto ambiental prévio à sua atuação (CORTE..., 2007, parágrafo n. 129).

No caso povos Kaliña e Lokono vs. Suriname, julgado em 2015, a mineradora BHP Billiton (também envolvida na "Tragédia de Mariana", em Minas Gerais, no Brasil, em novembro de 2015) exerceu atividade mineradora ao longo do Rio Suriname, contaminando-o com detritos, e causando prejuízo ambiental às reservas indígenas dos povos Kaliña e Lokono, que viviam da pesca no Rio Suriname (SANTOS; RIBEIRO, 2016, p. 392). Na sentença, a Corte Interamericana fez menção expressa aos Princípios Orientadores sobre Empresas e Direitos Humanos, reforçando o papel dos Estados em coibir violações praticadas por empresas aos direitos humanos por meio de medidas apropriadas para prevenir, investigar, castigar e reparar os danos (CORTE..., 2015, p. 62-63).

Em decisão recente, a Corte condenou o Brasil por permitir que particulares mantivessem trabalhadores em condições análogas a de escravos no julgamento do caso Trabalhadores da Fazenda Brasil Verde vs. Brasil. Embora não se tratasse de empresa transnacional, as considerações da Corte bem se aplicam a organizações desse porte. Nesse caso, o Estado Brasileiro não adotou medidas suficientes para coibir a violação da liberdade e da dignidade dos trabalhadores (CORTE..., 2016, p. 83). A omissão do Estado, quando presente seu dever de agir, foi o fator determinante da responsabilização (CORTE..., 2016, p. 84-85). Constata-se que não basta a existência de legislação como uma proposta política para lidar com o problema, deve o Estado se desincumbir de efetivo dever jurídico de garantir os direitos (MAGRAW, 2009, p. 486).

Verifica-se que em muitos casos (KALECK; SAAGE-MAAß, 2008, p. 22) os Estados dispõem de leis capazes de coibir ou reparar as violações, o que em tese poderia sugerir uma afinidade jurídica rumo ao lus Constitutionale Commune mencionado por Bogdandy. A responsabilização das empresas envolvidas, contudo, não se realiza por falta de aparato institucional preparado e disponível, seja nas searas administrativas de fiscalização da atuação das empresas, em órgãos que promovem o acesso ao Judiciário para as vítimas e mesmo na atuação desse próprio Judiciário. 


\section{Humanos e \\ Democracia}

Ainda que leis nacionais sejam o primeiro passo para a responsabilização de empresas transnacionais, de pouco servirão se não vierem acompanhadas de efetiva atuação estatal, delas se utilizando para uma real responsabilização. Ao falhar o Estado, pode-se desencadear sua responsabilização perante o sistema regional (SANTOS; RIBEIRO, 2016, p. 385).

Esse fator deveria servir como desestímulo para esses Estados, no sentido de controlar a atuação de corporações transnacionais que se instalassem em seu território para explorar mão de obra e recursos ambientais, bem como deveria impulsioná-los para a adequada diligência na proteção dos direitos humanos. Não é, todavia, o que ocorre: a pressão exercida pelo sistema interamericano de proteção não consegue fazer frente ao poder econômico das corporações transnacionais, ou mesmo a fatores políticos domésticos. A responsabilização dos Estados no sistema interamericano pode se mostrar de baixa eficácia se eles não incorporarem efetivamente as recomendações do sistema: parecem preferir manter atuantes as corporações transnacionais em seu território, a despeito de eventuais violações de direitos humanos.

O descompasso entre as recomendações do sistema interamericano e a realidade doméstica dos Estados pode comprometer a eficácia do sistema regional, como demonstra o caso da Usina Hidrelétrica Belo Monte, no Brasil. A Comissão Interamericana de Direitos Humanos, a fim de resguardar direitos de povos indígenas que ocupavam a Volta Grande do Rio Xingu, proferiu Medida Cautelar recomendando que o Brasil suspendesse as obras da Usina. O governo brasileiro mostrou-se francamente contrário à Medida, alegando que adotara todas as precauções exigíveis para salvaguardar os direitos dessas comunidades e que a obra era essencial para a produção de energia no país. Paralelamente, e em retaliação, o Brasil retirou a indicação de Paulo Vanuchi para integrar a Comissão. Em virtude de desgaste, a Comissão acabou por retirar sua Medida Cautelar (SICILIANO, 2011, p. 3).

Em outras situações, o que se percebe é que os Estados, ainda que não o queiram, são incapazes de conter o poder econômico de empresas transnacionais (BÖHM, 2012, p. 22-23).

Para que as determinações do plano interamericano em relação à proteção dos direitos humanos efetivamente encontrem adesão nos Estados nacionais, necessário se faz que eles reconheçam externalidades substanciais capazes de desencadear um elevado custo (moral, político, quiçá econômico) de deserção. Em muitos casos, os Estados não reconhecem essas externalidades internacionais como uma ameaça concreta, o que acaba por gerar um descrédito em relação ao sistema (SICILIANO, 2011, p. 4). Especialmente no caso de Belo Monte, o Estado brasileiro mostrou-se disposto a arcar com os riscos inerentes à construção da Hidrelétrica, favorecendo transnacionais como a Odebrecht, a Camargo Correa e a Andrade Gutierrez (PEREIRA; GOY, 2010), além da própria plataforma política nacional.

Assim, recomendações e condenações do sistema interamericano aos Estados não impedem novas violações de direitos humanos, nem logram corrigir adequadamente as violações ocorridas. Com isso, as corporações transnacionais não são responsabilizadas por violações de direitos humanos, uma vez que os governos locais não têm vontade ou força política para proteger esses direitos, ou carecem de habilidade para efetivar essa proteção. Justamente essa impunidade indica o quão importante é pensar alternativas de responsabilização, estendendo obrigações de respeito aos direitos humanos diretamente às empresas transnacionais, ou buscando outras jurisdições (BRABENDERE, 2009, p. 202). 


\subsection{Responsabilização perante Estados de origem ("Home States")}

Quando empresas transnacionais se instalam em Estados inaptos para desencadear sua responsabilização, poder-se-ia cogitar sobre a possibilidade de serem demandadas diretamente perante seu Estado de origem, onde está sua matriz ou centro decisório. Os Princípios Ruggie permitem essa manobra, a partir do dever de due diligence. Todas as corporações seja a matriz, sejam suas filiais, inclusive demais empresas que compõem a sua cadeia produtiva - têm o dever respeitar direitos humanos, independentemente de sua localização (SILVA; PAMPLONA, 2016, p. 158).

A prática processual de submeter uma empresa transnacional à jurisdição de seu Estado de origem, por atos praticados em outros Estados, é conhecida como jurisdição extraterritorial (ZUBIZARRETA, 2009, p. 325). Trata-se da aplicação "de uma lei nacional de um Estado a atividades que se realizam além de suas fronteiras, ou que ocorrem em território de outro Estado sem conexão com o dele próprio" (KALECK; SAAGE-MAA $\beta$, 2008, p. 27). Com isso, são "reterritorializados" os benefícios gerados pela atuação extraterritorial dessas empresas, como também sua responsabilidade por atos contrários ao Direito. No caso das corporações transnacionais, essa pode ser a única forma de responsabilizá-las quando têm sede em países da Europa ou na América do Norte, e desenvolvem ações nocivas aos direitos humanos em Estados do Hemisfério Sul.

Essa concepção conflitaria, a priori, com o princípio da territorialidade e da soberania, na medida em que implica a possibilidade de um Estado aplicar seu Direito Interno para tratar de atividades ocorridas em outros Estados, a partir do Direito Público Internacional. É preciso compreender, todavia, que quando um Estado falha no seu dever de garantir e proteger direitos humanos, mesmo em face de atos de terceiros, a própria noção de soberania passa por uma ressignificação. A soberania assume caráter relativo, servindo como um instrumento a serviço do ser humano a fim de justificar o exercício do poder estatal. Nesta qualidade, com sentido teleológico, acaba por autorizar a atuação de órgãos supranacionais em defesa dos direitos humanos, interferindo inclusive na aplicação do Direito Interno (FIGUEIREDO, 2012, p. 153). No caso da extraterritorialidade, admite-se buscar a jurisdição de um Estado para responsabilizar uma empresa por atividades adotadas em outro Estado, justamente porque violam os direitos humanos aos quais essas empresas devem respeito. Se o Estado de acolhimento não logra responsabilizá-las, poderia o Estado de origem fazê-lo. Nesse caso, o Direito Interno do Estado de origem serve como mecanismo de instituição e aplicação das normas de Direito Internacional.

Mesmo na ausência de um tratado internacional que autorize expressamente a extraterritorialidade, nesse sentido genérico (BRABENDERE, 2009, p. 203), a busca pela efetividade dos direitos humanos violados por empresas transnacionais tem impulsionado a atuação do sistema interamericano (SANTOS; RIBEIRO, 2016, p. 396).

Existem antecedentes de jurisdição extraterritorial na Comissão Interamericana de Direitos Humanos, como se depreende do Informe sobre a Situação dos Direitos Humanos no Chile em 1985, em que se identificou assassinato de funcionários do governo Salvador Allende por agentes de Inteligência Nacional norte-americana e argentina (CERQUEIRA, 2015, p. 19). Para a CIDH, a aplicação extraterritorial de normas jurídicas se justifica quando (i) os atos 


\section{Humanos e \\ Democracia}

ou omissões geradores de dano aos direitos humanos têm efeito para fora do Estado denunciado e (ii) o agente transgressor da obrigação internacional agiu sob a autoridade e controle efetivo do Estado denunciado (CERQUEIRA, 2015, p. 19). Para que esses requisitos se aplicassem a empresas, precisar-se-ia pensar em pessoas jurídicas cuja direção ou principal capital acionário pertence a um Estado, ou que ajam em seu nome no exercício de concessões públicas. ${ }^{4}$ Nessas hipóteses, a jurisdição extraterritorial encontra bom suporte jurídico (BRABENDERE, 2009, p. 203).

A aplicação da extraterritorialidade para casos envolvendo violações de direitos humanos por empresas privadas, todavia, precisa ser enfrentada.

Sobre o tema, uma das previsões normativas mais emblemáticas é o Alien Tort Claims Act (ATCA), nos Estados Unidos. Criada em 1789, essa lei permaneceu longo tempo em desuso, mas ressurgiu em 1980, quando do julgamento do caso Filartiga v. Peña-Irala, em que foi condenado Americo Norberto Peña-Irala, paraguaio responsável pela morte sob tortura de Joelito Filartiga, em 1976, no Paraguai, durante a ditadura militar. Segundo o Alien Tort Claims Act, as Cortes federais dos Estados Unidos têm ampla jurisdição para julgar todo caso civil baseado em uma violação do Direito Internacional, independentemente de onde a violação ocorreu, desde que a Corte tenha competência para julgar o acusado (MONGELARD, 2006, p. 688-689).

Embora nesse primeiro caso tenha se tratado de um indivíduo acusado de tortura no Paraguai, o ATCA já possibilitou o julgamento de empresas transnacionais, como se verificou no caso Doe vs. Unocal (MAGRAW, 2009, p. 472). Admitiu-se pela primeira vez uma ação civil de responsabilização de uma corporação privada por violação de direitos humanos: a Unocal se beneficiou do aparato estatal militar de Mianmar para garantir a construção de oleodutos, mediante o uso da força, o que gerou deslocamentos forçados, torturas e estupros. Embora a ação tenha se encerrado mediante acordo, passou uma mensagem: "The notion that U.S. courts were willing to hold corporations liable for complicity reverberated throughout the international corporate community, as many corporations were unsure of when they might face civil liability resulting from their foreign activities" (MAGRAW, 2009, p. 472).

Também com fundamento no ATCA, o caso Khulumani v. Barclay National Bank Ltd., estabeleceu parâmetros para a responsabilização de pessoas privadas por violação da lei internacional mediante apoio e suporte (cumplicidade): fornecer efetiva e deliberada assistência, com efeito substancial na perpetração de um crime (definido na lei internacional). Essa definição foi complementada pelo juiz Hall, para quem a responsabilização de corporações por cumplicidade na violação de direitos humanos pode ser definida pelos próprios Estados dotados de jurisdição para promovê-la (DANFORTH, 2011, p. 665).

Um problema a ser enfrentado para a responsabilização de empresas que violam direitos humanos é justamente identificar o Estado de origem. Zubizarreta (2009, p. 325) salienta que não basta identificar o domicílio da sede da corporação transnacional, pois pode não ser

\footnotetext{
Como se verificou no julgamento Ximenes Lopes vs. Brasil, pela Corte Interamericana de Direitos Humanos, quando reconheceu que não se pode distinguir entre as responsabilidades do Estado quando age diretamente, e de uma pessoa jurídica privada que age como concessionária do poder estatal, praticando atividade estatal (como serviços públicos de saúde) em seu nome (CERQUEIRA, 2015, p. 20).
} 
nesse domicílio que se encontra o núcleo responsável pelas tomadas de decisão. Os Estados de origem devem definir critérios jurídicos aptos a prever a responsabilidade de todos os setores da empresa, ou empresas, envolvidos nos processos decisórios que determinaram a violação de direitos humanos.

Um desses critérios é o da jurisdição pessoal ativa, ou seja, aplica-se o Direito do Estado de cuja nacionalidade é a empresa (sob qual direito ela se constituiu originalmente) (HOMA, 2016 , p. 3). Com isso, permite-se estender o princípio do Direito Internacional público de aut dedere aut judicare conjugado com o princípio da solidariedade às corporações transnacionais. Nesse caso, o princípio da solidariedade permitiria, de um lado, um regime de cooperação internacional para a efetividade extraterritorial das sentenças proferidas pelos Tribunais nacionais do Estado de origem, envolvendo vítimas que fossem seus nacionais, para atingir violações ocorridas no Estado de acolhimento, caso este não tenha condições de promover essa responsabilização (HOMA, 2016, p. 3-4).

No caso de empresas transnacionais que se estruturam a partir de pessoas jurídicas diversas, cada uma com uma nacionalidade, há quem defenda a adoção de uma presunção de que todos os atos praticados pelas empresas filiais contam com a anuência da "empresa-mãe", justamente em virtude do grau de interligação que existe entre essas empresas para que a cadeia produtiva funcione. Com essa presunção, poder-se-ia reduzir a aplicação da doutrina do forum non conveniens pelo Estado de origem (HOMA, 2016, p. 4), todavia há a evidente dificuldade em admitir tal presunção, eis que a responsabilização deve, via de regra, ser imputada a quem contribuiu para a ocorrência do dano e esse nexo entre a atuação ou omissão do agente e o dano ocorrido não é presumido, como regra geral.

Para além disso, a extraterritorialidade pode ser inferida de alguns documentos internacionais, todavia não há qualquer consenso sobre a possibilidade de sua ampla aplicação. Ao contrário, mesmo a Corte Interamericana de Direitos Humanos admite sua aplicação para casos específicos, por exemplo, quando o agente age em nome do Estado, como ocorreu no caso Ximenes Lopes, quando o Brasil foi condenado pelos maus tratos sofridos pela vítima em um centro de internamento.

\subsection{A proposta da jurisdição universal}

Diante das dificuldades apontadas para o exercício da jurisdição do Estado de acolhimento, ou mesmo do Estado de origem em casos de violação de direitos humanos por empresas transnacionais, a doutrina procurou apresentar uma nova alternativa para operacionalizar a responsabilização dessas corporações: a jurisdição universal.

Trata-se de utilizar a estrutura burocrática e coativa de um Estado para aplicar as regras do Direito Internacional a fim de reprimir violações. Esse Estado não precisa necessariamente ser aquele em que ocorreu a violação, nem precisam ser nacionais seus os envolvidos na afronta. Pode se tratar de um terceiro Estado completamente alheio ao caso, que age suplementarmente diante da impossibilidade de os demais agirem. Importante asseverar que a jurisdição universal não implica necessariamente um enfraquecimento da soberania dos Estados, mas sim sua reconfiguração, na medida em que a função por ela assumida seria exercer a justiça internacional (FASANO, 2011, p. 17-22). 


\section{Humanos e}

Democracia

Diferentemente da jurisdição extraterritorial, em que o Direito doméstico de um Estado (ainda que informado pelo Direito Internacional) se aplica a situações ocorridas em território de outros Estados, a jurisdição universal implica a possibilidade de um Estado investigar, julgar e punir práticas independentemente de onde tenham ocorrido, da nacionalidade do acusado ou de sua vítima. A ligação existente entre o Estado e a conduta que visa a punir é o repúdio à violação dos direitos humanos, pois afetam todos no panorama internacional. Mesmo que os causadores das violações sejam anistiados em seus Estados de origem, ou não sejam perseguidos nos Estados de acolhimento, estariam submetidos a um processo a ser desencadeado perante terceiros (ROBERTSON apud FASANO, 2011, p. 34). Como ressalta Cohen (2011, p. 145), um elemento essencial para a jurisdição universal é que a conduta ilícita seja matéria de interesse internacional.

A jurisdição universal foi concebida originalmente para o fim da persecução penal. Segundo um estudo intitulado "Projeto de Princetown sobre a competência repressiva universal", em 2001, ela corresponderia à "competência penal baseada somente na natureza do crime, sem considerar o local em que o crime tenha sido cometido, a nacionalidade do suposto ou condenado perpetrador, a nacionalidade da vítima, ou qualquer outra conexão com o Estado que exerce tal jurisdição" (FASANO, 2011, p. 32). Segundo essa proposta, caberia a um Estado, a partir da operacionalização do seu sistema jurídico penal, processar, julgar e punir alguém pela prática de um crime internacional grave, com impacto sobre a humanidade (FASANO, 2011, p. 36-37).

Na América Latina, a jurisdição universal tem sido utilizada em casos de impossibilidade de se responsabilizar perpetradores de crimes contra a humanidade e genocídio perante a jurisdição do Estado em que atuaram, ou em seus Estados de origem. $\mathrm{O}$ caso das tribos indígenas Aché, no Paraguai, é um exemplo. Na década de 70 o governo ditatorial promoveu o deslocamento forçado dessas tribos para uma fazenda particular, supostamente considerada uma "reserva", a fim de favorecer a expansão agrícola. Mais de $60 \%$ da população foi dizimada e os sobreviventes foram torturados e vendidos como escravos. As vítimas propuseram a ação na Argentina, com amparo na jurisdição universal, uma vez que não viram chance de obterem justiça em seu próprio país (TRIBO, 2014).

Essas hipóteses, contudo, ainda estão longe de lidar com a perspectiva da responsabilização de empresas transnacionais. Para esse caso, surgem duas dificuldades: de um lado, admitir que a jurisdição universal se aplique às corporações, e não só aos indivíduos, como tem ocorrido; e de outro, possibilitar que se promova a responsabilização civil, e não a imputação penal, para as violações de direitos humanos.

Segundo Magraw, a expansão da jurisdição universal para abarcar também pessoas jurídicas privadas poderia decorrer das situações em que elas dão suporte e apoio àqueles que cometem o crime. Nesse sentido, o próprio Estatuto de Roma admite, no artigo 25, 3, c, que pessoas sejam responsabilizadas e punidas se atuarem como cúmplices ou encobridores, ou colaborarem de qualquer forma com a deliberada prática de um crime. Essa previsão poderia permitir uma interpretação autorizadora da responsabilização de empresas quando elas exercessem atividades que favorecessem a prática de crimes de guerra, contra a paz, contra a humanidade e genocídio (MAGRAW, 2009, p. 481). 
Se é possível conceber que empresas transnacionais atuem de modo a contribuir com a ocorrência de crimes contra os direitos humanos, mais fácil seria viabilizar sua responsabilidade civil nesses casos, a fim de gerar a obrigação de reparar os danos. Nessa perspectiva, a jurisdição universal aplicável às empresas transnacionais poderia se mostrar mais viável para a maior parte dos Estados, que não admitem responsabilidade penal de pessoas jurídicas.

A aplicação da jurisdição universal às empresas transnacionais exige a colaboração dos Estados, para que admitam em sua legislação interna os mecanismos jurídicos capazes de responsabilizá-las. Nesse sentido, o Alien Tort Claims Act ou Alient Tort Statute (ATS) tem muito a contribuir para o fim de desencadear a jurisdição universal - e não só a aplicação do Direito norte-americano a fatos ocorridos em outro Estado. Nesse sentido:

The ATS is a jurisdiction-granting statute that does not create new substantive law. In enforcing specific, universal, and obligatory norms of international law through the ATS, U.S. courts are therefore not giving U.S. law extraterritorial reach. They are instead enforcing international law. Nothing in international law prohibits such enforcement; quite the contrary. Under the Lotus principle of international law, each nation-state has broad authority to exercise extraterritorial criminal and civil jurisdiction to enforce international law (MEYER; HATHAWAY, 2012, p. 2). ${ }^{5}$

Assim, a fim de preencher uma "lacuna de governança" internacional que se formou entre a baixa habilidade dos Estados (em desenvolvimento) em promover a responsabilização de corporações transnacionais por seus atos, caberia aos Tribunais domésticos exercer a jurisdição universal com base em suas obrigações perante o Estatuto de Roma e a Carta de Direitos Humanos (MAGRAW, 2009, p. 495).

Vale observar também que, embora o Estatuto de Roma trate da configuração de tipos penais, sob a ótica internacional as dimensões penal e civil não são concorrentes, mas complementares (COHEN, 2011, p. 144). O próprio Estatuto reconhece a possibilidade de se condenar o agressor a reparar o dano. Assim, a jurisdição civil universal teria cabimento para os mesmos casos em que se cogita da jurisdição penal, mostrando-se menos gravosa que a última, pois não implica penas restritivas da liberdade, mas serve para reconhecer a responsabilidade e determinar a reparação dos danos.

Diversas são as razões alegadas por Cohen (2011, p. 146) para justificar a jurisdição universal civil: (i) persecução penal e civil por graves violações de direitos humanos são os dois lados da mesma moeda, a partir do princípio do combate à impunidade e a exigência de accountability; (ii) o Alien Tort Claims Act (EUA) já funciona como um mecanismo para responsabilização dos agentes privados violadores de direitos humanos (inclusive corporações transnacionais), o que demonstra que o Direito interno dos Estados pode dar o primeiro passo para reconhecer esse tipo de jurisdição; (iii) a racionalidade que justificou a criação de uma jurisdição universal para julgamento de crimes que preocupam a humanidade também se aplica para a condenação a reparações, tornando mais efetivo o acesso à Justiça para as ví-

\footnotetext{
Essa citação consta da petição de amicus curiae apresentada pela Universidade de Yale no caso Kiobel, mas não foi a opinião da Corte. Trata-se de ação promovida por vítimas e familiares das vítimas da tribo Ogoni, da Nigéria, em face da Shell Petroleum Development Company (SPDC), por conta de sua colaboração com o regime militar do país no cometimento de várias violações de direitos humanos. O pedido foi fundamentado no Alien Tort Act, cuja aplicação foi afastada.
} 


\section{Humanos e}

Democracia

timas que não logram realizar suas pretensões perante o Direito Interno de seus países; (iv) a jurisdição civil universal também atenderia ao objetivo de combater a impunidade e (v) a concepção de um princípio poderoso como a jurisdição universal com a finalidade de perseguir ofensores deveria autorizar também uma contrapartida para as vítimas.

Em favor da jurisdição universal já se pronunciou o Comitê Internacional da Cruz Vermelha. Segundo este Comitê, as infrações de natureza grave previstas nas Convenções de Genebra, de 1949, e no seu Protocolo Adicional I, de 1977, demandam dos Estados-partes uma postura ativa, a fim de que promovam a devida responsabilização daqueles que supostamente cometeram esses delitos, independente da sua nacionalidade, perante sua estrutura jurisdicional doméstica, ou perante os Tribunais Internacionais competentes. Esses diplomas internacionais estariam em consonância ainda com a Convenção sobre Tortura (1984), e a Convenção sobre Desaparecimentos Forçados (2006), ambas prevendo a possibilidade de estabelecimento da jurisdição universal (COMITÊ..., 2015).

Até o presente momento não há tratado internacional autorizando a instituição da jurisdição universal civil para graves violações de direitos humanos por empresas transnacionais, mas, conforme indica a Base de Dados de Implementação Nacional do Direito Internacional Humanitário, do Comitê Internacional da Cruz Vermelha, diversos países já dispõem em sua legislação interna de mecanismos que autorizam a jurisdição universal - ainda que em caráter penal, mas que poderia, com algum esforço, ser estendida para responsabilização civil pelos argumentos já apresentados (COMITÊ..., 2018).

Pensando na América Latina, verificam-se exemplos na jurisdição criminal como o do artigo 118 da Constituição Argentina (1994), que prevê a possibilidade de jurisdição extraterritorial para suas Cortes. No Brasil, a previsão de jurisdição universal decorre do artigo 7으, II, do Código Penal, o qual afirma que o Judiciário brasileiro é competente para processar e julgar crimes que, em razão de tratados internacionais, o Estado se comprometeu em reprimir. No Uruguai, a Lei n. 18.026/2006 institui mecanismos de cooperação internacional para punição dos crimes previstos no Estatuto de Roma, inclusive estabelecendo que não deve haver limites para a persecução dos crimes de genocídio, crimes contra a humanidade e crimes de guerra (URUGUAY, 2006). Assim, vislumbra-se que a legislação nacional desempenha um papel essencial para operacionalizar a jurisdição universal.

A despeito da falta de tratado internacional, é possível encontrar elementos que delineiam minimamente esse instituto, a fim de se evitar sua aplicação de forma arbitrária (CAETANO, 2012, p. 6). A jurisdição universal seria aplicada apenas às mais graves violações de direitos humanos, notadamente aquelas que foram tipificadas como crime pelo Estatuto de Roma, ou seja, a importância da violação acabaria por determinar medidas extremas para autorizar seu julgamento (COHEN, 2011, p. 145; MAGRAW, 2009, p. 495).

Outro fator importante é a subsidiariedade: somente se justifica o recurso à jurisdição universal quando os Estados diretamente ligados à situação em que ocorreu a grave violação de direitos humanos não promoveram e não têm condições de promover a adequada persecução. Assim, a jurisdição universal surge da necessidade de fornecer uma resposta às vítimas precisamente quando o Direito falha, o que se viabiliza pela doutrina do fórum necessitatis (precisamente a contrapartida do fórum non conveniens): 
A doutrina do fórum de necessidade permite a um tribunal ouvir uma reclamação, mesmo quando os testes padrões para a competência não estão totalmente satisfeitos, se não houver nenhum outro fórum em que o demandante poderia razoavelmente procurar alívio. É, portanto, a imagem espelhada do forum non conveniens, que permite aos réus estabelecer que um tribunal não deve ouvir uma reclamação, apesar dos testes de competência terem sido cumpridos, com base em uma série de fatores discricionários. Enquanto as doutrinas operam em princípios semelhantes, forum non conveniens dá aos réus uma chance extra de "matar» um caso, enquanto fórum de necessidade dá aos demandantes uma chance extra para salvá-lo (HOMA, 2016, p. 5)

É certo que os tribunais do local em que ocorreu a violação podem ter mais facilidade para colher provas, inclusive com conhecimento de toda a conjuntura do Estado a fim de dar um provimento jurisdicional mais justo (CAETANO, 2012, p. 7). Muitas vezes, todavia é essa conjuntura que acaba por determinar a impunidade de certos grupos - especialmente quando se trata de empresas transnacionais que estabelecem alianças com governos a fim de facilitar a instalação de suas atividades. Ademais, os Tribunais locais podem ser corrompidos justamente pelo jogo das forças inerentes ao poder político sempre que graves violações de direitos humanos se verificam. É preciso ter em conta que crimes como os descritos no Estatuto de Roma e nas Convenções de Genebra dificilmente podem ser perpetrados sem que pessoas efetivamente poderosas forneçam suporte e condições materiais.

Desacreditar uma Corte somente em função da distância que ela guarda em relação ao local dos fatos, ou mesmo da nacionalidade, da cultura ou da história das pessoas envolvidas (CAETANO, 2012, p. 6) implicaria comprometer até mesmo a atuação das Cortes Internacionais, sem real base fática para tanto. Decisões adotadas por Cortes Internacionais, como a Corte Internacional de Justiça, voltam-se para o "fator humano", buscando precisamente conhecer com cuidado e detalhes a realidade vivida pelas pessoas que serão diretamente atingidas pela decisão (SANDOVAL, 2014).

De qualquer forma, há que se considerar que um mecanismo tão poderoso quanto ainda carente de delineação jurídica como a jurisdição universal pode representar um avanço no combate à impunidade de empresas transnacionais que violam direitos humanos.

\section{CONCLUSÃO}

Empresas transnacionais exercem atividades por todo o globo, não sendo diferente na América Latina, todavia o que torna os países latino-americanos atraentes para a sua expansão, em grande parte dos casos, são condições jurídicas pouco rígidas para a proteção de direitos humanos das populações envolvidas nessas atividades. A América Latina, dependente dos investimentos financeiros estrangeiros, é institucionalmente fraca para coibir abusos.

Diante dessa realidade, referidas empresas transnacionais não podem estar à margem do direito internacional dos direitos humanos. Ainda que não haja um tratado internacional comprometendo-as direta e taxativamente, é possível extrair de tratados e declarações internacionais uma obrigação geral atribuível às empresas de respeitar direitos humanos, a qual independe de sua qualificação como pessoas jurídicas de Direito Internacional, pois é exercida e cobrada dentro da esfera nacional dos Estados. 


\section{Humanos e \\ Democracia}

Além disso, documentos jurídicos de soft law como os Princípios Ruggie exigem um compromisso de empresas transnacionais em relação aos direitos humanos. Embora desprovidos de mecanismos de eficácia, têm o condão de orientar a produção legislativa e atuação administrativa dos Estados, e ao menos expor as empresas internacionalmente via propaganda negativa quando descumprem esse compromisso. Como o Direito não se estrutura exclusivamente por meio de coerção, é possível deduzir que essas normas possam desencadear uma institucionalidade de responsabilização por parte das empresas.

Fato é que essa responsabilização precisa passar pela atuação dos Estados.

No caso dos Estados latino-americanos de acolhida ("host states") existe, na maior parte dos casos, um aparato legislativo capaz de obrigar empresas transnacionais a respeitar os direitos humanos, no entanto se essas leis não são acompanhadas de uma atuação institucional efetivamente comprometida, violações ocorrem e não são responsabilizadas. O poder econômico das empresas fala mais alto, e os Estados muitas vezes aceitam pagar o preço político de desrespeitarem sua obrigação de garantir a fruição dos direitos humanos perante a comunidade internacional para manter em seu solo, atuantes, as empresas transnacionais.

Como alternativa, existe a jurisdição extraterritorial, ou seja, a responsabilização das corporações perante seu Estado de origem ("home states"). Nesse caso, o Direito interno do Estado de origem, antenado e comprometido com a esfera internacional de proteção dos direitos humanos, acaba por ser um canal de aplicação dessas normas. Uma das dificuldades diz respeito à distância do juiz em relação ao local da violação, o que muitas vezes sugere a aplicação da doutrina do fórum non conveniens, de modo a comprometer a responsabilização ao jogar o processo precisamente para o Estado sem condições de conduzi-lo com isenção ou rigor. Outro fator complicador é a descentralização das transnacionais, dificultando a identificação do Estado de origem.

Finalmente, quando falham Estados de acolhimento e Estados de origem, surge a proposta da jurisdição universal civil, em que qualquer Estado comprometido com a repressão a graves violações de direitos humanos poderia desencadear um processo de responsabilização das empresas sem com elas guardar vínculo de nacionalidade, tampouco com as vítimas ou ainda com o local em que tenha ocorrido a violação. Trata-se de mecanismo carente ainda de maior profundidade conceitual, bem como dependente da adesão do Direito interno dos Estados, a fim de institucionalizar essa operacionalização.

Diante do exposto, pode-se afirmar que a responsabilização de empresas transnacionais permanece tema controverso, para a qual, contudo, já se apontam algumas possíveis soluções. Essa responsabilização deve ser feita com segurança e seriedade, para se tornar efetiva e atingir seus objetivos. Parafraseando o procurador no Tribunal Penal de Nuremberg, Robert H. Jackson, não se pode aceitar o paradoxo jurídico em que a responsabilidade seja a menor, quando o poder é o maior.

\section{REFERÊNCIAS}

BAARS, G. Capitalism's Victor's Justice? The Hidden Stories Behind the Prosecution of Industrialists Post-WWII. In: HELLER, K. J.; SIMPSON, G. The Hidden Histories of War Crimes Trials. Oxford: Oxford University Press, 2013.

BÖHM, M. L. Empresas transnacionales y violaciones de Derechos Humanos en América Latina: Dificultades para su imputación y juzgamiento. Boletín Semestral Grupo Latinoamericano de Investigación Penal Göttingen, n. 4, jul./dic. 2012, p. 11-24. 
BRABENDERE, E. Non-State Actors, State-Centrism and Human Rights Obligations. Leiden Journal of International Law, n. 22, jan. 2009, p. 191-209. Available from: https://ssrn.com/abstract=1352623. Cited: 5 maio 2018.

CAETANO, F. A. K. e. Sobre a possibilidade de uma competência universal para a garantia do direito à memória. E-Civitas, v. 5, n. 1, jul. 2012. Disponível em: http://revistas.unibh.br/index.php/dcjpg/article/view/750. Acesso em: 11 jul. 2018.

CANÇADO TRINDADE, A. A. Condición Jurídica y Derechos de los Migrantes Indocumentados: voto concordante do Juiz A. A. Cançado Trindade no Parecer n. 18 da Corte Interamericana de Direitos Humanos, de 17 de setembro de 2003. In: CANÇADO TRINDADE, A. A. Os Tribunais Internacionais e a realização da Justiça. Rio de Janeiro: Renovar, 2015.

CANÇADO TRINDADE, A. A. Tratado de Direito Internacional dos Direitos Humanos. Porto Alegre: Sérgio Antônio Fabris, 1997. Vol. I.

CARDIA, A. C. R.; GIANNATTASIO, A. R. C. O Estado de Direito Internacional na Condição Pós-Moderna: a força normativa dos princípios de Ruggie sob a perspectiva de uma Radicalização Institucional. In: BENACCHI, M. (coord.); VAILATTI, D. B.; DOMINIQUINI, E. D. (org.). A sustentabilidade da relação entre empresas transnacionais e Direitos Humanos. Curitiba: CRV, 2016. p. 127-146.

CERQUEIRA, D. La atribución de responsabilidad extraterritorial por actos de particulares en el sistema interamericano: contribuciones al debate sobre empresas y derechos humanos. Aportes DPLf, n. 20, año 8, ago. 2015. Disponible en: http://www.corteidh.or.cr/tablas/r35399.pdf. Acceso en: 20 jun. 2018.

COHEN, M. Between offenders and victims: the civil dimension of universal jurisdiction. Revista do Instituto Brasileiro de Direitos Humanos, v. 11, n. 11, p. 141-153, 2011.

COLÔMBIA. Plano de Ação Nacional para Empresas e Direitos Humanos. Disponível em: http://www.ohchr.org/ Documents/Issues/Business/NationalPlans/PNA_Colombia_9dic.pdf. Acesso em: 16 jul. 2018.

COMITÊ INTERNACIONAL DA CRUZ VERMELHA. O escopo e a aplicação do princípio de jurisdição universal: declaração do CICV nas Nações Unidas, 2015. Disponível em: https://www.icrc.org/pt/document/o-escopo-e-aplicacao-do-principio-da-jurisdicao-universal-declaracao-do-cicv-nas-nacoes. Acesso em: 11 jul. 2018.

COMITÊ INTERNACIONAL DA CRUZ VERMELHA. National Implementation of IHL. Geneve. Disponível em: https:// ihl-databases.icrc.org/ihl-nat. Acesso em: 11 jul. 2018.

CORTE INTERAMERICANA DE DIREITOS HUMANOS. Caso Velásquez Rodríguez Vs. Honduras. Sentença de 29 de julho de 1988 (Mérito). Disponível em: http://www.cnj.jus.br/files/conteudo/arquivo/2016/04/2ed9f5488d3b613fb7364d2008a0c3a1.pdf. Acesso em: 20 abr. 2018.

CORTE INTERAMERICANA DE DIREITOS HUMANOS. Caso do Povo Saramaka Vs. Suriname. Sentença de 28 de novembro de 2007 (Exceções Preliminares, Mérito, Reparações e Custas). Disponível em: http://www.cnj.jus.br/ files/conteudo/arquivo/2016/04/cc1a1e511769096f84fb5effe768fe8c.pdf. Acesso em: 20 abr. 2018.

CORTE INTERAMERICANA DE DIREITOS HUMANOS. Caso Pueblos Kaliña y Lokono vs. Surinam. Sentencia de 25 de noviembre de 2015. (Fondo, Reparaciones y Costas). Disponible en: http://www.corteidh.or.cr/docs/casos/ articulos/seriec_309_esp.pdf. Acceso en: 9 jul. 2018.

CORTE INTERAMERICANA DE DIREITOS HUMANOS. Caso Trabajadores de la Hacienda Brasil Verde vs. Brasil. Sentencia de 20 octubre de 2016 (Excepciones Preliminares, Fondo, Reparaciones y Costas). Disponible en: http:// www.corteidh.or.cr/docs/casos/articulos/seriec_318_esp.pdf. Acceso en: 7 jul. 2018.

DANFORTH, M. E. Corporate Civil Liability Under the Alien Tort Statute: Exploring Its Possibility and Jurisdictional Limitations. Cornell International Law Journal, v. 44, p. 660-691, 2011.

FASANO, R. R. A competência repressiva universal no direito internacional penal. 2011. 187p. Dissertação (Mestrado em Direito) -Universidade de São Paulo, São Paulo, 2011. Disponível em: file:///C:/Users/Ana/Downloads/ Renata_Rossini_Fasano_ME\%20(1).pdf. Acesso em: 2 jul. 2017.

FIGUEIREDO, M. La internacionalización del orden interno en clave del derecho constitucional transnacional. In: VON BOGDANDI, A.; PIOVESAN, F.; MORALES ANTONIAZZI, M. (org.). Estudos Avançados de Direitos Humanos. 2. ed. Rio de Janeiro: Elsevier, 2012. p. 143-177.

HOMA. Centro de Direitos Humanos e Empresas. As obrigações dos Estados de origem: suas obrigações extraterritoriais nas violações de direitos humanos por corporações transnacionais. 2016. Disponível em: http://homacdhe.com/wp-content/uploads/2016/06/AS-OBRIGAC\%CC\%A70\%CC\%83ES-DOS-ESTADOS-DE-ORIGEM.pdf. Acesso em: 10 jul. 2017.

KALECK, W.; SAAGE-MAA $\beta$, M. Transnational Corporations on Trial: on the Threat to Human Rights Posed by European Companies in Latin America. v. 4 in the Publication Series on Democracy. Berlin: Heinrich-Böll-Stiftung, 2008. KALECK, W.; SAAGE-MAA $\beta$, M. Corporate Accountability for Human Rights Violations Amounting to International Crimes: The Status Quo and its Challenges. Journal of International Criminal Justice, Oxford: Oxford University Press, n. 8, p. 699-724, 2010. 


\section{Humanos e \\ Democracia}

LIMA, A. L. C. Globalização econômica e política e Direito: análise das mazelas causadas no plano político-jurídico. Porto Alegre: Sérgio Antônio Fabris, 2002.

LOPES, R. A. L. A responsabilização de empresas transnacionais por violações a direitos humanos sob a perspectiva do direito internacional. ENCONTRO NACIONAL DO CONPEDI, 23., Florianópolis, UFSC 30 abr. a 2 maio 2014, p. 123138. Disponível em: http://www.publicadireito.com.br/artigos/?cod=4410a22591c15bc7. Acesso em: 19 jun. 2018. MAGRAW, K. Universally Liable? Corporate-Complicity Liability Under the Principle of Universal Jurisdiction. Minnesota Journal of International Law, v. 18, n. 2, p. 458-497, 2009. Available from: http://lawweb3.law.umn.edu/ uploads/rR/O3/rRO3ojA_UIsJPyL54xOtaQ/Magraw-Final-Online-PDF-03.30.09.pdf. Cited: 27 jun. 2018.

MEYER, J. A.; HATHAWAY, O. A. Suplemental Brief of Yale Law School Center for Global Legal Challenges as Amicus Curiae in Support of Petitioners. Supreme Court of The United States. Esther Kiobel et al. v. Royal Duthc Petroleum Co. et al., jun. 2012. Available from: http://documents.law.yale.edu/kiobel-v-royal-dutch-petroleum-yale-law-school-center-global-legal-challenges-amicus-curiae-brief-so. Cited: 2 jul. 2018.

MEZA, A. Venezuela anuncia sua retirada da OEA: governo Maduro toma decisão após a organização convocar reunião para analisar a situação do país. El País, Caracas; Washington, 27 abr. 2017. Disponível em: http://brasil. elpais.com/brasil/2017/04/27/

internacional/1493246051_378028.html. Acesso em: 2 jul. 2018.

MONGELARD, E. Corporate civil liability for violations of international humanitarian law. International Review of the Red Cross, v. 88, n. 863, sep. 2006.

OKIMURA, E. Y. A dignidade da pessoa humana e o direito ao trabalho decente no contexto da globalização. In: PIOVESAN, F.; FACHIN, M. G. (coord.). Direitos humanos na ordem contemporânea: proteção nacional, regional e global. Curitiba: Juruá, 2012. p. 305-329. V. 5.

PAUST, J. J. Human Rights Responsabilities of Private Corporations. Vanderblit Journal of Transnational Law, v. 35, may 2002, n. 3. Available from: https://papers.ssrn.com/sol3/papers.cfm?abstract_id=1548112. Cited: 19 jun. 2018.

PEREIRA, R.; GOY, L. Três maiores empreiteiras construirão Belo Monte. Estadão, São Paulo, 14 ago. 2010. Disponível em: http://economia.estadao.com.br/noticias/

geral,tres-maiores-empreiteiras-construirao-belo-monte,594852. Acesso em: 9 jul. 2018.

PETERS, A. Membership in the Global Constitutional Community. In: KLABBERS, J.; PETERS, A.; ULFSTEIN, G. The Constitutionalization of International Law. Oxford: Oxford University Press, 2012.

PIOVESAN, F. Direitos humanos e justiça internacional. 6. ed. rev., ampl. e atual. São Paulo: Saraiva, 2015.

SANDOVAL, P. X. "Acima dos Estados estão os seres humanos que os compõem" Entrevista: Antônio Cançado Trindade. El País, Madri, 1ㅇ abr. 2014. Disponível em: https://brasil.elpais.com/brasil/2014/03/31/internacional/1396300000_175731.html. Acesso em: 12 jul. 2018.

SANTOS, M. L. S.; RIBEIRO, C. F. T. Empresas e Direitos Humanos na Instância Interamericana de Proteção dos Direitos Humanos. In: BENACCHIO, M. (coord.); VAILATTI, D. B.; DOMINIQUINI, E. D. (Org.). A sustentabilidade da relação entre empresas transnacionais e Direitos Humanos. Curitiba: CRV, 2016. p. 383-403.

SICILIANO, A. L. O Caso de Belo Monte na Comissão Interamericana de Direitos Humanos: análise em dois níveis. São Paulo, out. 2011. Disponível em: http://www.academia.edu/3264486/O_CASO_DE_BELO_MONTE_NA_COMISS\%C3\%830_INTERAMERICANA_DE_DIREITOS_HUMANOS_AN\%C3\%81LISE_EM_DOIS_N\%C3\%8DVEIS. Acesso em: 9 jul. $20 \overline{18}$.

SILVA, A. R. F.; PAMPLONA, D. A. Os Princípios Orientadores das Nações Unidas sobre Empresas e Direitos Humanos: houve avanços? In: BENACCHIO, M. (coord.); VAILATTI, D. B.; DOMINIQUINI, E. D. (org.). A sustentabilidade da relação entre empresas transnacionais e Direitos Humanos. Curitiba: CRV, 2016. p. 147-168.

TOMUSCHAT, C. Human Rights Between Idealism and Realism. 3. ed. Oxford: Oxford University Press, 2014.

TRIBO da América do Sul leva governo do Paraguai a julgamento por genocídio histórico. Diário Liberdade. 8 jun. 2014. Disponível em: https://www.diarioliberdade.org/america-latina/repressom-e-direitos-humanos/ 49784-tribo-da-am\%C3\%A9rica-do-sul-leva-governo-do-paraguai-a-julgamento-por-genoc\%C3\%ADdio-hist\%C3\%B3rico.html. Acesso em: 11 jul. 2018.

URUGUAY. Ley № 18.026 de Cooperacion con la Corte Penal Internacional en Materia de lucha contra el Genocidio, los Crimenes de Guerra y de Lesa Humanidad, 2006. Diario Oficial № 27091, 4 Octubre 2006. Disponible en: www.parlamento.gub.uy/leyes/ley18026.htm. Aceso: 10 mar. 2016.

VON BOGDANDY, A. Ius Constitutionale Commune na América Latina: uma reflexão sobre um constitucionalismo transformador. In: VON BOGDANDY, A.; MORALES ANTONIAZZI, M.; PIOVESAN, F. (coord.). Ius Constitutionale Commune na América Latina: Marco Conceptual. Curitiba: Juruá, 2016. p. 11-52. V. 1.

ZUBIZARRETA, J. H. Las Empresas Transnacionales frente a los Derechos Humanos: história de una asimetría normativa, Bilbao: Hegoa e Omal, 2009. Disponível em: http://publicaciones.hegoa.ehu.es/assets/pdfs/79/Empresas_transnacionales_frente_a_los_derechos_humanos.pdf?1488539221. Acesso em: 19 jun. 2018. 